\title{
BCECBITHЯ ICTOPIЯ
}

УДК 316.3: 061.2 (09) (438)

DOI https://doi.org/10.32838/2663-5984/2019/4.20

Беззубенко А.В.

Харківський національний педагогічний університет імені Г.С. Сковороди

\section{РОЛЬ НЕУРЯДОВИХ ОРГАНІЗАЦІЙ У ФОРМУВАННІ ГРОМАДЯНСЬКОГО СУСПІЛЬСТВА У ПОЛЬЩІ (1990-ті роки)}

\begin{abstract}
У статті аналізується проиес становлення громадянського суспільства у Польщі в 1990-х роках. Зокрема, досліджуються причини активізачії діяльності неурядових організачій після 1989 року, щзо виступали важливим структурним елементом демократичної держави. Встановлено, що ідея громадянського суспільства на початку 1990-х років набула великого поширення серед польського населення та політиків у зв'язку зі зміною концепиії функиіонування польської держави як у політичній, так $і$ в сочіально-економічній сферах. Унаслідок падіння комуністичного режиму перед держсвою та громадянами постали нові виклики $i$ завдання. Після 1989 року спостерігаємо появу багатьох нових польських неурядових організацій та ренесанс тих організачій, діяльність яких була заборонена комуністичною владою. Активну діяльність започаткувала ще у 1980-х роках «Солідарність». Такі організащії, як Гельсінський комітет, Товариство Помост, Польсько-Чесько-Словаџька Солідарність, легалізували свою роботу, стаючи в такий спосіб першою платформою, на якій безпосередньо вирішувалося завдання відбудови громадянського суспільства в державі. Одними з перших у Польщі запрацювали також аналітичні («мозкові») центри (think tanks), що виступали важливими акторами в напраџюванні стратегії становлення громадянського суспільства. Дані неурядові організації прагнули відродити сочіальні иінності та громадську активність, розширити можливості для участі польських громадян у політичній, сочіальній, економічній, культурній сферах тошо. Ці питання набувають все більшого значення, адже у другій половині 1990-х років Республіка Польща однією з перших краӥн Центрально-Східної Свропи заявила про своє членство в Свропейському Союзі як про свою стратегічну мету. Бажання входу Польщі до иієї структури виражали практично всі впливові політичні сили та значна частина польського суспільства. Активну діяльність у изьому напрямі здійснювали також польські неурядові організащії та фундаиії.
\end{abstract}

Ключові слова: демократія, громадянське суспільство, неурядові організачіï, фундація, «мозкові» иентри, західна допомога.

Постановка проблеми. Трансформаційні процеси у країнах Центрально-Східної Свропи, що розпочалися на межі 80-90-х рр. ХХ ст., продемонстрували принципово різні результати у сфері соціально-економічного, суспільно-політичного, культурного розвитку та становлення інститутів державної влади у країнах даного регіону. Польща стала однією 3 перших країн, що пішла шляхом глибоких демократичних перетворень. Успішний перехід країни до формування засад демократичного суспільства, ринкової економіки значною мірою був полегшений як підтримкою міжнародних організацій та фондів, так і активною діяльністю третього сектора в Польщі. Під третім сектором сьогодні частіше всього розу- міють сукупність усіх неурядових організацій, фундацій і товариств, що створюються для досягнення соціальних, благодійних, освітніх, культурних, гуманітарних цілей, і не ставлять за мету отримати прибуток.

Неурядові організації в сучасних демократичних суспільствах відіграють надзвичайно важливу роль. Вони представляють інтереси певних соціальних груп або всього суспільства в діалозі із владою, виражають конкретні соціальні цінності, норми суспільного життя; є джерелом інновацій у вирішенні безлічі соціальних проблем; сприяють зміцненню громади та соціальної солідарності; виконують функцію контролю, насамперед щодо державного управління [9, с. 7]. 
Аналіз останніх досліджень і публікацій. Польський третій сектор $є$ предметом наукового дослідження в основному соціологів, політологів, правознавців, рідше це предмет історичного дослідження. Роль неурядових організацій у формуванні громадянського суспільства у країнах Центрально-Східної Свропи взагалі та Польщі зокрема досліджували такі закордонні і вітчизняні вчені: М. Бухарін [1], О. Макухін [2], Л. Чекаленко [5], Г. Маковський [8], М. Новосельський [9], Й. Шмідт [12].

Постановка завдання. Мета статті полягає в дослідженні і визначенні ролі польських неурядових організацій у становленні громадянського суспільства у країні у 1990-х рр.

Виклад основного матеріалу дослідження. 1990-ті рр. позначилися активною фазою трансформації т.зв. суспільств радянського типу у Союзі Радянських Соціалістичних Республік (далі - СРСР) і країнах Центрально-Східної Європи (далі - ЦСС). Далеко не останню роль у цій трансформації відіграли неурядові організації (далі - НУО). Різкий темп виникнення польських НУО фіксуємо в першій половині 1990-х рр. Соціолог М. Римша назвав це «ефектом зняття кришки» - як пар виривається з котла, так і неурядові організації (далі - НУО) неочікувано виникали в польському суспільному житті [3]. Динамічне збільшення кількості НУО стало результатом політичних змін унаслідок падіння комуністичного режиму, які започаткували створення нового соціально-економічного простору, що раніше був заповнений в основному державою. Додатковим стимулом став зростаючий соціальний попит із боку різних груп населення, зменшення довіри до державних установ, які не могли задовольнити всі потреби й очікування громадян у досліджуваний період.

Безпосередньо термін «громадянське суспільство» було популяризовано наприкінці 1970-х на початку 1980-х рр. активістами опозиційних демократичних рухів Чехословаччини, Польщі й Угорщини. Просуваючи стратегію «соціальної самоорганізації», підкреслюючи роль ініціатив населення, опозиціонери прагнули відродити соціальні цінності та громадську активність, розширити можливості для участі громадян у політичній, соціальній, економічній, культурній сферах тощо. На думку О. Макухіна, звільнення публічного простору для громадянського суспільства в Польщі стало заслугою насамперед профспілки «Солідарність», що сприяло значній демократизації життя у країні [2, с. 29].
Швидке відновлення польського третього сектора вимагало налагодження співпраці 3 державними органами та коригування законодавства. Основні правила для визначення існування незалежних організацій громадянського суспільства були гарантовані Законом «Про товариства» 1989 p. (Ustawa Prawo o stowarzyszeniach z dnia 7 kwietnia 1989 roku (z pyźn. zmianami)) [14] і в Конституційному акті 1992 р. Остаточні гарантії функціонування громадських організацій були визначені в Конституції 1997 р. Відповідно до ст. 12 Основного закону, Польська Республіка забезпечує свободу творення і діяльності профспілок, суспільно-професійних організацій, товариств, громадських рухів та інших добровільних об'єднань і фундацій [7]. У преамбулі принцип субсидіарності поставлений у ряд основоположних конституційних принципів державного ладу й означає, що створені організації діють на благо громадян, представляють їхні інтереси, захищають цінності членів суспільства, надають низку послуг, допомагають людям у повсякденному житті.

Профільним законом щодо взаємодії органів публічної адміністрації з НУО став Закон від 24 квітня 2003 р. «Про діяльність суспільного блага і волонтаріат» (Ustawa o działalnośći pozytku publicznego i o wolontariacie) [13], який у Польщі називають «конституцією» неурядових організацій. Цей Закон уперше дає юридичне визначення НУО, діяльності суспільної користі (на благо суспільства), іiі суб'єктів, регулює принципи здійснення такої діяльності, іiї використання органами публічної адміністрації, визначає форми взаємодії та сфери публічних завдань. Ухвалення цього Закону є одним із найбільших досягнень громадянського суспільства в Польщі. Він надав цивілізованого характеру відносинам між державною і муніципальною адміністрацією, 3 однієї сторони, і організаціями, націленими на суспільне благо, - 3 іншої. Сьогодні майже кожна гміна у Польщі співпрацює з НУО, влаштовує конкурси, виділяє гранти - і все це $є$ доволі прозорим.

Відомо, що спочатку важливу функцію у становленні громадянського суспільства у країнах ЦСЄ взагалі й Польщі зокрема відігравали західні фонди та міжнародні організації. На початку 1990-х рр. вони з великим оптимізмом концентрували свою увагу на польських НУО. Підтримувалися передусім правозахисні, екологічні організації, групи, які займалися моніторингом виборів, об'єднання із правової освіти громадян, незалежні засоби масової інформації. Основна ідея полягала 
в наданні підтримки особам і організаціям, що обстоювали нові свободи, були політично переконаними прибічниками громадянського суспільства, яке, у свою чергу, повинно було стати «інкубатором» демократії [1, с. 32]. Інше завдання, яке стояло перед польським неурядовим сектором, це залучити громадян до участі в місцевому самоврядуванні, до роботи закладів охорони здоров'я, освітніх установ тощо.

Початок 1990-х рр. був періодом високої динаміки у створенні нових неурядових організацій. За даними організації Klon/Jawor, наприкінці 1989 р. в Польщі було зареєстровано 289 організацій, у 1990 р. - ще 862 нових, у 1991 р. - 998 організацій, у 1992 р. - 1115 організацій, у 1993 р. - 740 організацій, у 1994 р. - 425 організацій, у 1995 р. 310 організацій [11, с. 53-54]. Сфера діяльності польських НУО охоплювала практично всі галузі життя громадян - економіку, політику, науку, культуру, освіту. Сформувалась розгалужена мережа молодіжних, професійних, дитячих, жіночих, ветеранських, релігійних, а також елітарних організацій-клубів, «мозкових центрів» (think tank).

Аналізуючи вплив надання західної допомоги на становлення громадянського суспільства у Польщі, можна побачити, що цей процес у досліджуваний період пройшов принаймні два етапи. Перший етап був коротким і збігся $з$ ідеалістичною ейфорією початку 1990-х рр. Західні приватні інститути та деякі офіційні агентства встановлювали перші контакти 3 новими незалежними польськими громадськими об'єднаннями й активістами, які виступали на захист суспільних інтересів. Також велика увага приділялась незалежним засобам масової інформації [9, с. 20]. Другий етап, який розпочався із середини 1990-х рр. і тривав до кінця 1999 р., позначився розширенням мережі НУО. Західні донори, як і раніше, розуміли під наданням допомоги підтримку неурядових організацій, однак діапазон таких організацій і допомоги, наданої їм, був значно розширений. Допомога тепер направлялась більш широкому колу НУО: не тільки політично орієнтованим правозахисним групам, але й організаціям, які надавали певні послуги, наприклад, у сфері захисту прав дітей, охорони здоров'я, соціальна допомога тощо. У зв'язку з тим, що третій сектор у Польщі швидко збільшувався (особливо у першій половині 1990-х рр.) і вже включав у себе тисячі різноманітних організацій, донори розпочали підтримувати центри підготовки та розвитку польських НУО [9, с. 21].

До Польщі приїздили представники найвідоміших міжнародних неурядових організацій. Серед них: Фонд Форда (США), Фонд братів Рокфеллерів (США), Фонд Конрада Аденауера (Німеччина), Фонд ім. Фрідріха Еберта (Німеччина), які також підтримували польські неурядові організації. 3 початком 1990-х рр. активну діяльність не теренах Польщі запровадив Фонд ім. Джорджа Сороса (США) через мережеву програму «Схід - Схід» (програма сприяння міжнародному партнерству посткомуністичних країн Свропи та пострадянських країн Азіі). Вони ділилися досвідом своєї діяльності (організаційною структурою, можливими джерелами фінансування, новітніми формами роботи).

Ініціаторами неурядової діяльності у країні також стали інституції, що доти або були заборонені, або мали напівлегальний статус. Активну діяльність започаткувала ще в 1980-х рр. «Солідарність». Такі організації, як Карта, Гельсінський комітет, Товариство Помост, ПольськоЧесько-Словацька Солідарність, легалізували свою роботу, стаючи в такий спосіб першою платформою, на якій безпосередньо вирішувалося завдання відбудови громадянського суспільства в державі.

У 1992 р. було розроблено дві програми, що фінансово підтримували розвиток громадянського суспільства в Польщі, зокрема НУО. Програма «PHARE - Суспільний Діалог» як один із фінансових інструментів Європейського Союзу для країн-кандидатів із ЦСЄ у підготовці до вступу до даної міжнародної організації. У 1993 р. розпочинає свою діяльність проєкт «PHARE 0-22» 3 метою підтримки співробітництва неурядових організацій із публічною адміністрацією у сфері соціальної допомоги. Одним із його суттєвих результатів стало створення Регіональних центрів підтримки (далі - РЦП) у Гданську, Катовіце, Любліні, Познані та Варшаві [4].

Протягом 1994 р. в Польщі відбулися кілька важливих заходів. Серед них: Регіональний форум неурядових ініціатив (м. Познань), Келецький форум неурядових організацій (м. Люблін), на якому, зокрема, уперше зустрілися тренери неурядових організацій (які в майбутньому створять Об'єднання тренерів НУО). У Гдині, Варшаві, Сопоті та Гданську були затверджені Програми співробітництва між міською владою і НУО, головними завданнями яких були ділове співробітництво в реалізації муніципальних завдань, що полягали не тільки в передачі коштів із бюджету міста організаціям, але також у використанні професійного потенціалу даних НУО під час визначення потреб суспільства, оцінки попередньої 
роботи міської влади, пошуку нових підходів до вирішення тієї чи іншої проблеми [4].

21-22 вересня 1996 р. у Варшаві відбувся I Загальнопольський форум неурядових організацій. Організатори Форуму ставили за мету створити місце для діалогу, обміну досвідом між польськими НУО щодо подальшого розвитку громадянського суспільства, а також місця та ролі активних громадян у ньому. Це була гарна можливість показати свої досягнення, різноманітність неурядових організацій і громадських ініціатив у Польщі. У Форумі взяли участь також представники державної та місцевої адміністрації, парламенту, підприємці, засоби масової інформації. Загалом понад 3 тис. осіб, включаючи представників понад 800 польських та іноземних громадських організацій [10]. Фіналом тижня став пікнік неурядових організацій з усієї Польщі.

Отже, вищеперелічені заходи сприяли тому, що все більша кількість польських НУО залучалися до формування місцевої політики. Для порівняння: від 16\% НУО у 1993 р. до 29\% у 1996 р. [2, с. 31].

У жовтні 1998 р. Рада міністрів затвердила рапорт «Співпраця урядової адміністрації з неурядовими організаціями» [4]. Уряд вирішив розпочати роботу над проєктом закону про співпрацю публічної адміністрації з НУО. У грудні 1998 р. приблизно 400 організацій підписали розроблений Асоціацією підтримки Форуму неурядових ініціатив меморандум, що висвітлював урегулювання правових умов праці неприбуткового сектора в Польщі. У ньому містився заклик проведення т. зв. п'ятої реформи - більшого включення громадської активності в систему державного управління [12, с. 111].

Отже, уведення чітких правових принципів функціонування третього сектора в Польщі (може, у дечому недосконалих) було одним із важливих чинників нормалізації діяльності неурядових організацій. Це збільшило діапазон впливу третього сектора. Зміни, які були введені в польському законодавстві, дозволили співпрацювати НУО 3 державною адміністрацією та місцевою владою.

Одними 3 перших у Польщі запрацювали аналітичні («мозкові») центри (think tanks), що виступали важливими акторами в напрацюванні стратегії становлення громадянського суспільства. У першій половині 1990-х рр. у Польщі діяло до 10 відомих аналітичних центрів, які намагалися більше впливати на політичні процеси у країні, ініціювати, стимулювати позитивні зміни в державному управлінні, формувати громадську думку. Особливістю польських «мозкових» центрів стало те, що вони сформувались як осередки інтелектуалів, професіоналів, результати діяльності яких відображались у політиці провідних державних діячів країни. Серед них: Фундація розвитку місцевої демократії (Fundacja Rozwoju Demokracji Lokalnej, FRDL, 1989 p.), Інститут Центральної і Східної Свропи (Instytut Europy Środkowo-Wschodnej, 1991 p.), Інститут польської політики (Instytut polskiej polityce, 1992 р.), Міжнародний центр розвитку демократії, МЦРД (Międzynarodowe Centrum Rozwoju Demokracji, 1992 р.), Інститут приватного підприємництва i демократіï (Instytut Badań nad Demokracją i Przedsiębiorstwem Prywatnym, 1993 p.), Інститут досліджень основ демократії (Instytut Badań nad Podstawami Demokracji, 1995 р.) тощо.

Так, Фундація розвитку місцевої демократії (далі - ФРМД) була створена в серпні 1989 р. за ініціативою сенатора Єжи Регульського, проф. Валер'яна Панько, Анджея Целінського, Александра Пашинського та Єжи Стемпеня - активістів демократичної опозиції 1980-х рр. Свою місію організація вбачала у поширенні ідей громадянського суспільства як фундаментальної форми демократії. Діяльність Фундації була спрямована на розвиток громадського самоврядування, підтримку місцевих органів влади та місцевих адміністрацій, місцеве самоврядування. Організація ініціювала заходи для працівників самоврядування і депутатів місцевих рад, представників НУО, журналістів, учителів, молоді, працівників і кадрів малих та середніх підприємств, а також безробітних або людей, яким загрожувало безробіття. Наприклад, протягом першого року свого існування послугами мережі консультаційних центрів, створених Фундацією для надання правової й організаційної допомоги у сфері функціонування місцевого самоврядування, скористалися 20 тис. осіб, майже 2 тис. осіб стажувалися за кордоном [2, с. 30]. Як зазначено на офіційному сайті організації, за 25 років було організовано навчальні курси для 1,4 млн осіб у Польщі та за кордоном [6].

Від самого початку своєї діяльності ФРМД співпрацювала 3 багатьма інституціями, організаціями, товариствами і фундаціями Західної Європи та США, які підтримували демократичні перетворення в Польщі. 3 моменту свого створення Фундація швидко розрослася у велику організацію, яка мережею своїх структур охоплює всю територію Польщі. Нині ФРМД - це: 14 регіональних навчальних центрів; 4 Вищі 
школи публічної адміністрації (ВШПА/WSAP) у Бєлостоці, Кельцах, Лодзі, Щецині; Польський інститут місцевої демократії (ПIMД/PILD); Центр програм боротьби із соціальною безпорадністю; Видавництво літератури з питань самоуправління.

Висновки. Коли в 1989 р. розпочалися великі політичні, економічні та соціальні зміни в Польщі, спричинені падінням комуністичного режиму, здавалося, що відродити демократичні цінності це справа легка. Однак із часом з'ясувалося, що трансформація - це втомливий, важкий процес, який потребує численних соціальних витрат. Незважаючи на це, через 30 років після початку демократичних змін можна сміливо сказати, що Польща досягла своєї мети. Одним зі стовпів польської демократії, безсумнівно, став третій сектор.

Після 1989 р. польські неурядові організації переживають свій ренесанс завдяки здобутій свободі зібрань. Більшість дослідників вказують на 1989 р. як на «рік перемоги громадянського суспільства», підкреслюючи, що пробудження ініціа- тиви населення є одним із найцінніших досягнень періоду трансформації. Поряд із НУО, які відновили свою діяльність, були створені різноманітні нові фундації та товариства.

Зростання ролі третього сектора в Польщі можна пояснити такими причинами: скороченням державних соціальних витрат першої половини 1990-х pp. і, відповідно, державної допомоги тим, хто іiї потребував; зростанням очікувань і активності громадян. Польські НУО активно впливали на політичні процеси у країні як виразники громадської думки. Серед причин активізації діяльності неурядових організацій у Польщі важливе місце посідає західна допомога, що базувалася на фінансуванні діяльності даних НУО як способу впливу і на політичну ситуацію у країні.

Досвід діяльності багатьох неурядових організацій засвідчив, що їхня активність мала очевидні переваги: гнучкість, мобільність, ініціативність, знання справ на місцях тощо, які стали важливими чинниками на шляху Польщі до громадянського суспільства.

\section{Список літератури:}

1. Бухарин Н. Строительство гражданского общества в странах Центральной и Юго-Восточной Европы. 90-е гг. XX в. - начало XXI в. Новая и новейшая история. 2005. № 1. С. 26-49.

2. Макухин А. Институализация гражданского общества и процесс реформирования системы самоуправления в Республике Польша. Социум и власть. 2016. № 6 (62). С. 29-33.

3. Мицнер М. Центр гражданского образования. Новая Польша. 2012. № 1. С. 21-23. URL: https:// www.novayapolsha.pl/pdf/2012/01.pdf.

4. Хроника третьего сектора в Польше. URL: http://rus.ngo.pl/x/302348.

5. Чекаленко Л. Специфіка формування громадянського суспільства в Республіці Польща. Історичний досвід становлення інститутів громадянського суспільства в країнах Європи : збірник наукових праць. Київ : Фоліант, 2012. С. 261-272.

6. Fundacja Rozwoju Demokracji Lokalnej. URL: https://frdl.org.pl.

7. Konstytucja Rzeczypospolitej Polskiej z dnia 2 kwietnia 1997 r. Dziennik Ustaw Rzeczypospolitej Polskiej. 1997. № 78. P. 483.

8. Makowski G. Rozwój sektora organizacji pozarządowych w Polsce po 1989 r. Studia BAS. 2015. № 4 (44). S. 57-85. URL: http://orka.sejm.gov.pl/wydbas.nsf/0/D611EC55BC25774FC1257F4000422DBE/\%24File/ Strony\%20odStudia_BAS_44-4.pdf.

9. Nowosielski M. Odradzanie się społeczeństwa obywatelskiego. Rozwój polskiego trzeciego sektora w latach 1989-2008. Poznań : Instytut Zachodni, 2008-2009. 64 s.

10. Ogólnopolskie Forum Inicjatyw Pozarządowych. URL: http://ofip.eu/historia-ofip/.

11. Organizacje pozarządowe w społeczeństwie obywatelskim / Pod red. Małgorzaty Załuskiej i Jerzego Boczonia. Katowice : Śląsk, 1998. 178 s.

12. Schmidt J. Rozwój organizacji pozarządowych. Teoria i praktyka. Sedno, 2012. $176 \mathrm{~s}$.

13. Ustawa o działalnośći pozytku publicznego i o wolontariacie. Dziennik Ustaw Rzeczypospolitej Polskiej. 2003. № 96. P. 873.

14. Ustawa Prawo o stowarzyszeniach z dnia 7 kwietnia 1989 roku (z pyźn. zmianami). Dziennik Ustaw Rzeczypospolitej Polskiej. 1989. № 20. Poz. 104.

\section{Bezzubenko A.V. THE ROLE OF NONGOVERNMENTAL ORGANIZATIONS IN THE FORMATION OF CIVIL SOCIETY IN POLAND (1990)}

The article analyzes the process of civil society formation in Poland in the 1990's. In particular, the causes of nongovernmental organizations after 1989, which have been an important structural element of a 
democratic state, are being investigated. It was found that the idea of civil society in the early 1990s became widespread among the Polish population and politicians due to the change in the concept of the functioning of the Polish state in both political and socio-economic spheres. The fall of the communist regime has brought new challenges and challenges to the state and its citizens. Since 1989, there have been numerous emergence of new Polish NGOs and the renaissance of organizations banned by the communist regime. He began his active work in the 1980's Solidarity. Organizations such as the Helsinki Committee, the Pomost Society, the Polish-Czech-Slovak Solidarity have legalized their work, thus becoming the first platform to directly address the challenge of restoring civil society in the country. Poland's think tanks were also among the first in Poland to play an important role in developing a strategy for civil society formation. These nongovernmental organizations sought to revive social values and civic engagement, expand opportunities for Polish citizens to participate in political, social, economic, cultural spheres, and more. These issues are of increasing importance, since in the second half of the 1990's, the Republic of Poland, one of the first countries of Central and Eastern Europe, declared its membership of the European Union as its strategic goal. The desire to enter Poland into this structure was expressed by virtually all influential political forces and a large part of Polish society. Polish nongovernmental organizations and foundations were also active in this area.

Key words: democracy, civil society, nongovernmental organizations, foundation, think tanks, western help. 